\title{
EFEKTIVITAS PENERAPAN PENILAIAN OTENTIK PEMBELAJARAN BAHASA INDONESIA UNTUK PENINGKATAN KINERJA ILMIAH SISWA
}

\author{
Nusrotus Sa’idah ${ }^{\bowtie}$, Hayu Dian Yulistianti, dan Yushinta Eka Farida
}

Fakultas Tarbiyah dan Ilmu Keguruan UNISNU Jepara

\section{Info Artikel}

Sejarah Artikel:

Diterima: 28 Sept 2017

Disetujui: 28 Okt 2017

Dipublikasikan: Des 2017

\section{Keywords:}

Authentic Assessment, Study of Bahasa Indonesia Scientific Performance

\section{Abstract}

The aims of the study are to determine the effectiveness of three authentic assessments appilcations, there are project appraisal, performance appraisal and portfolio assessment. The methodelogy used in this research is experimental study that used three classes of sampling and each class used different treatment of authentic assessment. The sample of the research is the students of class $X$ in MA Darul Ulum Purwogondo Jepara with random sampling. This research is preceded by requirement data test that is homogeneity test p-value 0,163 as a result which showed sample taken identical because more than sig 0,05. The results show that there is a difference in the mean value of three authentic assessment apps with p-value 0.00. Among the three assessments the most effective is the portfolio assessment with the mean difference showing the value of 3.371.Therefore, authentic assessment is very effective in learning to improve students' scientific performance.

\begin{abstract}
Abstrak
Penelitian ini bertujuan untuk mengetahui keefektifan dari penerapan ketiga penilaian otentik, yaitu penilaian proyek, penilaian kinerja dan penilaian portofolio. Metode penelitian menggunakan penelitian eksperimen dengan sampel tiga kelas yang dikenai tiga perlakuan penilaian otentik yang berbeda. Sampel penelitian yaitu siswa kelas X MA Darul Ulum Purwogondo Jepara dengan pengambilan random. Penelitian ini didahului dengan uji persyaratan data yaitu uji homogenitas dengan hasil p-value 0,163 yang menunjukkan sampel yang diambil identik karena lebih dari sig 0,05 . Hasil penelitian menunjukkkan ada perbedaan nilai rata-rata dari ketiga penerapan penilaian otentik dengan p-value 0,00 . Diantara ketiga penilaian tersebut yang paling efektif adalah penilaian proyek dengan mean difference menunjukkan nilai 3,371. Oleh karena itu penilaian otentik sangat efektif dilakukan dalam pembelajaran untuk meningkatkan kinerja ilmiah siswa.
\end{abstract}

\footnotetext{
$\triangle$ Alamat korespondensi:

Program Studi Pendidikan Guru Sekolah Dasar

Fakultas Keguruan dan Ilmu Pendidikan Universitas Muria Kudus

Kampus UMK Gondangmanis, Bae Kudus Gd. L. 1t I PO. BOX 53

Kudus

Tlp (0291) 438229 ex.147 Fax. (0291) 437198

E-mail: nusrotussaidah17@gmail.com
} 


\section{PENDAHULUAN}

Pendidikan merupakan dasar dalam menyiapkan sumber daya manusia yang berkualitas. Dalam mencerdaskan kehidupan bangsa guru mempunyai pmaeran penting dalam kegiatan tersebut. Bukan hanya sekedar mengajar saja yang menjadi tugas guru tetapi memberikan kebijakan penilaian hasil belajar juga menjadi aktivitas seorang guru.

Aktivitas belajar siswa perlu dirubah dalam meningkatkan kemampuan peserta didik. Untuk mendapatkan hasil belajar yang baik maka diperlukan aktivitas fisik dan mental yang baik. Semakin baik aktivitas belajar siswa maka hasil belajar juga akan meningkat. Bukan hanya kemampuan kognitif saja tetapi secara menyeluruh aktivitas siswa terkoordinir dengan baik yaitu aspek afektif dan psikomotorik.

Penilaian hasil belajar sebenarnya bukan hanya menitikberatkan pada aspek kognitif saja tetapi sampai dengan aspek afektif dan psikomotorik. Siswa yang mempunyai kemampuan tinggi belum tentu dapat menerapkan dengan baik jika diuji dengan paper-and-pencil test. Penilaian hasil belajar mempunayi tujuan meningkatkan kemampuan peserta didiksecara menyeluruh sesuai denga klasifikasi Bloom yaitu cognitive, affective dan psychomotor.

Perubahan paradigma dalam pembelajaran tidak hanya mengenai strategi pembelajaran tetapi sampai dengan penilaian. Paradigma penilaian dulu cenderung menilai pada kemampuan aspek kognitif saja dengan menyajikan soal yang belum terstandar.

Teori belajar konstruktivisme mengungkapkan bahwa dalam pembelajaran tidak hanya mengukur aspek kognitif saja tetapi mencakup aspek kepribadian, aspek perkembangan moral, aspek sosial. Oleh karena itu dalam paradigma penilaian tidak hanya bertumpu pada hasil melainkan proses (Dzulkifli \& Fithriya, 2015) .

Kunandar (2014) menyatakan bahwa salah satu penekanan dalam kurikulum 2013 adalah pada penilaian hasil belajar dimana guru harus menerapkan penilaian otentik. Penilaian otentik ini bertujuan untuk mengukur kemampuan peserta didik serta keberhasilan dalam mencapai tujuan pembelajaran. Dengan adanya penilaian otentik ini guru dapat melakukan evaluasi terkait perencanaan, pelaksanaan dalam pembelajaran terhadap kualitas yang dilakukan melalui penilaian hasil belajar.

Penilaian otentik ini untuk mengetahui apakah siswa serius dalam melaksanakan pembelajaran, apakah pembelajaran mempunyai dampak yang positif terhadap perkembangan siswa baik secara intelektual maupun mental siswa (Hosnan, 2014). Siswa tidak hanya dinilai pengetahuan saja tetapi ketrampilan dan sikap siswa sehari-hari. Siswa yang mempunyai daya intelektual tinggi belum tentu mempunyai ketrampilan yang memadai dan sikap yang baik.

Cordell \& Fisher (2010, pp. 480-481) menyebutkan keterkaitan antara pembelajaran dengan penilaian sangat berarti jika penilaian yang efektif maka proses pembelajaranakan lebih bermakna dan bermanfaat pada tujuan akhirnya. Azim \& Khan (2012, p. 318) menambahkan bahwa dengan meninjau hasil kegiatan penilaian dalam pembelajaran maka dapat diketahui peningkatan hasil belajar peserta didik. Olehkarena itu dengan penilaian dapat menentukan keputusan selama proses pembelajaran dengan mengintegrasikan penilaian secara komprehensif proses pembelajaran.

Paradigma penilaian yang tertera dalam peraturan pemerintah Nomor 19 (2005) pasal 25 tentang Standar Nasional Pendidikan mendeskripsikan standar kompetensi lulusan sebagai pedoman penilaian setiap mata pelajaran. Selanjutnya perbaikan standar penilaian dalam kurikulum 2013 pada Permendikbud Nomor 104 (2014) mempersyaratkan penggunaan penilaian otentik/authentic assessment.

Penilaian otentik ini realita integrasi penilaian sikap, pengetahuan dan ketrampilan. Dengan adanya revisi penilaian ini menuntut kerjasama sekolah yang terdiri dari kepala sekolah, pendidik, dan peserta didik serta para pendukung dalam meningkatkan motivasi belajar siswa. Adanya model penilaian otentik ini menyebutkan bahwa muncul adanya ketidakpuasan terhadap tes tulis yang lazim digunakan oleh para pendidik. Tes tertulis ini bukan berarti dihapus tetapi penilaian otentik ini sebagai pendukung untuk mengetahui kompetensi peserta didik yang sebenarnya.

Kunandar (2013) menyatakan bahwa penilaian otentik ini menekankan pada apa yang harus dinilai, baik proses maupun hasil dengan berbagai instrumen untuk mengukur kompetensi peserta didik. Penilaian ini untuk mengetahui informasi yang valid dan reliabel tentang apa yang diketahui atau dilaksanakan oleh peserta didik. Berbeda dengan penilaian tradisional yang hanya cenderung pada proses mengetahui tanpa melihat apa yang dilakukan oleh peserta didik.

Penilaian kinerja juga sangat diperlukan untuk mengetahui tingkat keberhasilan siswa dalam memahami materi yang sudah diberikan didalam kelas. Penilaian kinerja atau yang sering disebut dengan Performance assessment secara khusus dapat dideskripsikan sebagai penilaian 
yang mengukur keamampuan dan sikap peserta didik yang di buktikan dengan suatu perbuatan. Berdasarkan pemaparan beberapa ahli bahwa penilaian kinerja adalah penilaian terhadap pemerolehan, menerapkan pengetahuan dan keterampilan yang membuktikan kemampuan siswa dalam proses pemebelajaran maupun hasil produk yang di dapatkan. Dalam penilaian ini mengacu beberapa standar yang tertentu.

Menurut Wulan menulis beberapa standar yang dibutuhkan dalam penilaian kerja antara lain menganalisis dan mengidentifikasi secara jelas apa yang seharusnya peserta didik pahami, ketahui dan apa yang harus dilakukan. Standar di atas dinamakan dengan rubrik.

Rubrik dinyatakan merupakan panduan dalam pemberian skor yang membuktikan jumlah kriteria kinerja (performance) terhadap proses atau hasil. Rubrik berisi tingkatan nilai yang didapat oleh peserta didik dari yang paling buruk hingga yang paling baik. Dengan mengggunakan rubrik pendidik dapat memberikan nilai kinerja siswa. Selain rubrik itu sendiri, penilaian kerja mempunyai beberapa point yaitu tugas-tugas. Tugas (task) menunjukka suatu performance (kinerja) tertentu yang di bebankan kepada peserta didik.

Performance Assessment menurut Mark L. Merickle yang dikutip oleh Mundilarto (2006) bertujuan untuk meguji kemmaapuan peserta didik dalam menunjukkan pengetahuan dan keterampilan dalam beberapa dan konteks. Peserta didik biasa diminta untuk bekerja kelompok, menerapkan keterampilan dan konsep dalalm menyelesaikan tugas-tugas secara kompleks.

Dalam penilaian kinerja dapat berupa kegiatan menulis, merevisi, atau mempresentasikan hasil aporan di dalam kelas, melakukan percobaan atau eksperimen dan menganalisis hasilnya. Dalam mengetahui aktivitas peserta didik menggunakan observasi dapat berupa daftar cek atau skala penilaian.

Penilaian kinerja ini dapat menggunakan portofolio, portofolio itu sendiri dasarnya merupakan kumpulan karya individual peserta didik yang dalamnya menggambarkan ide-ide, keterampilan, prestasi dan minat pada subyek tertentu. Kegiatan ini melibatkan peserta didik dan orang tua untuk mnegetahui kemauan dalam subyek tersebut. Mundilarto (2006) menyebutkan beberapa langkah untuk menetapkan nilai pada tugas-tugas portofolio,seperti kerangka konseptual yang menggambarkan materi dan proses yang akan dinilai, mengembangkan pedoman secara rinci urutan materi dari awal sampai akhir, mengembangkan penskoran sesuai dengan pedoman secara rinci.
Project Based Learning (PBL) merupakan pembelajaran berbasis proyek memungkinkan proses pembelajaran berpusat pada peserta didik, peserta didik memahami masalah yang dikerjakan dalam proyeknya, menantang peserta didik menemukan masalah, melibatkan peserta didik untuk memecahkan permasalahan, mengambil keputusan sehingga memberika peluang peserta didik untuk mengerjakan proyek. Dengan adanya pembelajaran ini maka membutuhkan asesmen yang tepat dalam mengukur kompetensi peserta didik (N. Yahya, 2014). Aktivitas pembelajaran berbasis proyek menyediakan langkah kerja peserta didik untuk mengeksplor ide dan kreativitas sehingga dapat menghasilkan produk.

$$
\text { Pembelajaran berbasis proyek }
$$
menggunakan prinsip learning by doing merupakan prinsip belajar dengan melakukan tindakan tertentu. Proyek yang diberika peserta didik berhubungan dengan lingkungan sekitar membuka pandangan bahwa apa yang dialami peserta didik merupakan bahan kajian untuk membuat tugas proyek (Tri Winarti dan Sri Nurhayati , 2014: 1409). Dengan adanya penilain proyek ini dapat mengetahui kreativitas peserta didik sesuai dengan kemampuan. Dipertegas dalam penelitian (Addiin, et al., 2014) yang menyatakan bahwa dapat meningkatkan kreativitas, aktivitas dan hasil belajar peserta didik.

Pembelajaran bahasa Indonesia diarahkan untuk meningkatkan kemampuan peserta didik untuk berkomunikasi dalam Bahasa Indonesia dengan baik dan benar, baik secara lisan maupun tulis, serta menumbuhkan apresiasi terhadap hasil karya kesastraan manusia Indonesia. Dalam hal ini standar kompetensi lulusan untuk siswa khususnya materi Bahasa Indonesia peserta didik mampu menggambarkan penguasaan pengetahuan, ketrampilan berbahasa dan sikap yang positif terhadap sastra indonesia. Komponen utama dalam pembelajaran bahasa adalah menyimak, membaca, menulis dan berbicara (Burhan, 2007). Dalam pembelajaran Bahasa Indonesia, siswa juga diajak untuk berpikir dan bekerja secara ilmiah.

Empat kompetensi dalam pembelajaran Bahasa Indonesia yaitu, kemampuan menyimak, membaca, menulis dan berbicara. Kemampuan menyimak dan membaca termasuk aktif reseptif sedangkan menulis dan berbicara termasuk aktif produktif (Taufina, 2009). Pengembangan kurikulum 2013 pada mata pelajaran Bahasa Indonesia menggunakan pembelajaran berbasis teks. Diharapkan siswa mampu menggunakan teks dan memekreasikan sesuai dengan fungsi dan tujuannya, Bahasa Indonesia diajarakan 
bukan sekadar sebagai pengetahuan bahasa merupakan sebagai pembelajaran teks yang sesuai dengan konteks sosial- budaya akademisnya.

Hasil wawancara dengan para guru yang mengikuti FGD dalam pengenalan penilaian otentik pembelajaran bahasa ini menyatakan adanya faktor yang kurang mendukung yaitu waktu yang dimilki guru sangat terbatas dalam menyusun instrumen penialain otentik ini, pola kepemimpinan sekolah , kurang siapnya peserta didik dalam menghadapi paradigma penilaian baru, fasilitas belajar yang belum memadai secara lengkap dan faktor lingkungan yang kuang kondusif untuk mengaplikasikan pembelajaran dengan penilaian yang nyata. Dengan adanya temuan tersebut maka peneliti mengajak para pendidik untuk menyisihkan waktu dalam mengelola pembelajaran terutama dalam hal penilaian yang nyata.

Studi yang dilakukan tentang penialian otentik menunjukan bahwa penilaian ini berdampak positif terhadap kinerja pendidik dan hasil yang didapatkan oleh peserta didik juga meningkat. Taufina (2009) menyatakan bahwa penilaian authentic secara riil mengukur kinerja siswa secraa tepat dan peserta didik secara aktif dan produktif dalam proses pembelajaran.

Penelitian Suyoso (2006) menuliskan bahwa penilaian otentik dapat direalisasikan instrumen berupa tes tertulis, tes kinerja dan portofolio dan perangkat pembelajraan. Kemampuan pendidik dapat meningkat dalam pengajaran mata pelajaran fisika menggunakan metode creative learning secraa aplikatif. Sama halnya penelitian yang diakukan oleh Wijayanti (2014), memberikan hasil bahwa penilaian otentik berbasis proyek menggunakan pendekatan scientific yang telah dikembangkan dapat meningkatkan keterampilan berpikir ilniah dengana sangat efektif. Pada setiap aspek ketrampilan berpikir secraa ilmiah yanag dimiliki mahasiswa semakin meningkat. Hasil yang didapat secara keseluruhan peningkatan (gain) keterampilan berfikir sebesar 0,86 yang artinya peningkatan kriterianya sangat tinggi.

Berdasarkan uraian diatas maka peneliti ingin mengimplementasi penilaian otentik ini dilakukan dalam proses pembelajaran Bahasa Indonesia kelas $\mathrm{X}$ di MA Darul Ulum Purwogondo Jepara. Penelitian ini untuk mengetahui efektivitas pembelajaran dengan penilaian otentik yaitu penilaian proyek, kinerja dan portofolio. Penelitian ini dilihat dari aktivitas peserta didik dan hasil belajar Bahasa Indonesia dengan instrumen penilaian otentik yang berbasis life skill.

\section{METODE PENELITIAN}

Penelitian ini merupakan rangkaian dari pengembangan "Model Authentic Assessment dalam Pembelajaran Bahasa Indonesia Berbasis Life Skill'. Salah satu rangkaian penelitian ini adalah uji coba pada responden untuk mengetahui keefektifan dari penilaian otentik. Metode yang digunakan dalam penelitian ini adalah metode eksperimen untuk mengetahui efektivitas antara pembelajaran dengan implementasi penilaian kinerja, proyek dan portofolio.

Populasi penelitian adalah seluruh siswa kelas X MA Darul Ulum Purwogondo dengan teknik pengambilan Purposive Sampling. Pengambilan sampel dipilih tiga kelas dengan pembelajaran implementasi penilaian proyek, kinerja dan portofolio.

Dalam penelitian ini masing-masing diperoleh nilai hasil belajar dari implementasi penilaian otentik. Instrumen yang digunakan dalam penelitian ini adalah instrumen penilaian proyek, penilaian kinerja, dan portofolio dalam pembelajaran Bahasa Indonesia. Instrumen penilaian dilengkapi dengan rubrik penilaian. Hasil dari tugas ini berupa bahan diskusi, produk penulisan puisi dan portofolio siswa.

Teknik analisis data dalam penelitian ini menggunakan uji One Way Anova atau analisis satu jalur. Uji persyaratan data yakni uji normalitas untuk mengetahui apakah data dari penelitian ini berdistribusi normal dan uji homogenitas untuk mengetahui sampel yang diambil dari kedua kelompok mempunyai sifat identik atau homogen.

\section{HASIL PENELITIAN DAN PEMBAHASAN}

Data Hasil implementasi penelitian menunjukkan bahwa uji persyaratan data yaitu uji homogenitas menyatakan Sig 0,163. Hasil ini menunjukkan lebih besar dari 0,05 yang mempunyai interpretasi bahwa sampel dari penelitian ini adalah bersifat homogen yang dapat dilihat dalam tabel 1. Setelah analisis uji persyaratan data dilanjutkan untuk uji hipotesis.

Tabel 1. Hasil Analisis Uji Homogenitas

\begin{tabular}{lllll}
\hline $\begin{array}{l}\text { Levene } \\
\text { Statistic }\end{array}$ & df1 & df2 & Sig & Kesimpulan \\
\hline $\mathbf{1 , 8 4 6}$ & 2 & 102 & 0,163 & Homogen \\
\hline
\end{tabular}

Dari hasil analisis lanjut menunjukkan bahwa nilai $\mathrm{F}$ hit sebesar 81,628 dengan sig. 0,000 . Hasil analisis ini menunjukkanbahwa nilai sig < 0,05 maka kesimpulan ada perbedaan ratarata skor penilaian antara penilaian proyek, kinerja, dan portofolio. Dengan adanya 
perbedaan diantara ketiga penilaian tersebut maka analisis dilanjutkan untuk mengetahui penilaianyang lebih efektif. Hasil analisis dapat dilihat pada tabel 2 .

\begin{tabular}{llll}
\multicolumn{4}{c}{ Tabel 2. Hasil Analisis Anova } \\
F & P- & Tingkat & Kesimpulan \\
hitung & value & signifikansi & \\
\hline $\mathbf{8 1 , 6 2 8}$ & 0,000 & 0,05 & $\mathrm{H}_{\mathrm{o}}$ ditolak $/ \mathrm{H}_{\mathrm{a}}$ diterima \\
\hline
\end{tabular}

Analisis uji lanjut untuk mengetahui perbedaan antar kelompok secara spesifik sekaligus mengetahui diantara ketiga kelompok yang memiliki rata-rata teknik penilaian paling tinggi. Dari hasil analisis menunjukkan bahwa penilaian portofolio dengan penilaian kinerja nilai $\operatorname{sig}=0,776$, oleh karena nilai sig > 0,05 dapat disimpulkan bahwa tidak ada perbedaan skor rata-rata penilaian portofolio dengan kinerja atau portofolio.

Hasil analisis pada tabel 3 berikut penilaian dengan portofolio lebih tinggi dibanding dengan penilaian kinerja. Di antara ketiga penilaian yang diterapkan yang paling efektif, yakni penilaian dengan proyek. Hasil mean difference menunjukkan 3,371. Nilai ini menunjukkan sangat efektif dibanding dua penilaian yaitu penilain kinerja dengan portofolio.

Tabel 3. Hasil Analisis Data Multiple Comparisons

\begin{tabular}{ccccc}
\hline $\begin{array}{c}\text { Model } \\
\text { penilaian }\end{array}$ & Sig & $\begin{array}{c}\text { Mean } \\
\text { Difference }\end{array}$ & Kesimpulan \\
\hline 1 & 2 & 0,000 & 3,371 & Ho ditolak/Ha diterima \\
& 3 & 0,000 & 3,286 & \\
2 & 1 & 0,000 & $-3,371$ & Ho ditolak/Ha diterima \\
& 3 & 0,776 & $-0,086$ & Ho diterima/ha ditolak \\
3 & 1 & 0,000 & $-3,286$ & Ho ditolak/Ha diterima \\
& 2 & 0,776 & 0,086 & Ho diterima/ha ditolak \\
\hline
\end{tabular}

Menurut Nino Nurjananto* dan Ersanghono Kusumo (2015) menyatakan bahwa secara efektif instrumen penilaian otentik dapat mengukur kompetensi peserta didik dengan masing-masing menggunakan instrumen yang berbeda sesuai dengan kebutuhan. Dipertegas oleh Tutut Rukmana, Mundilarto mengungkapkan bahwa keterlaksanaan penilaian otentik ini dengan kategori baik meskipun ada beberapa faktor kendala dalam pelaksanaanya meliputi materi, waktu, kondisi sekolah dan kemampuan pendidik yang dipengaruhi oleh beban kerja disekolah.

Dari hasil uji One way Anova ini menunjukkan ada perbedaan yang signifikan antara ketiga pembelajaran dengan penilaian otentik. Rata-rata penilaian otentik ini menunjukkan bahwa penilaian proyek lebih efektif dibanding dengan penilaian kinerja dan portofolio. Hasil analisis terlihat pada statistik deskriptif berikut ini.

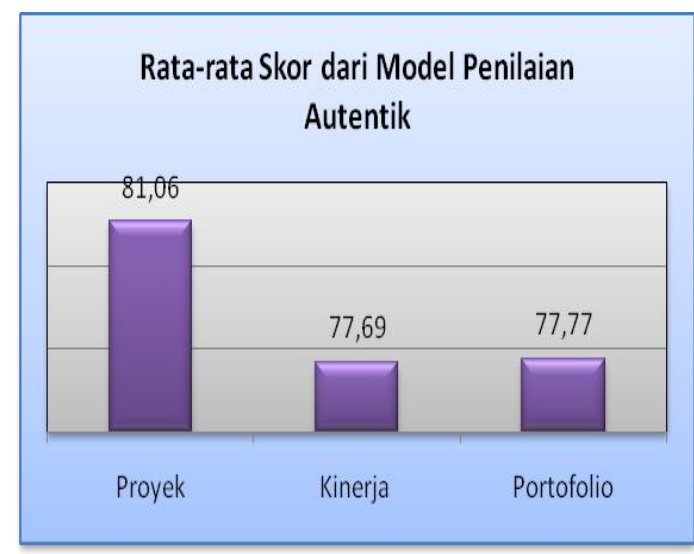

Penilaian proyek lebih efektif karena memberikan kesempatan siswa untuk mengeksplor ide dalam penulisan puisi terlibat kerjasama tim sehingga terbiasa untuk berhubungan, berkomunikasi dan menghargai orang lain. Dengan adanya penilaian proyek yang dilaksanakan dapat meningkatkan kemampuan ketrampilan siswa serta dapat menghasilkan produk berupa karya tulis siswa. Project Based Learning (PBL) merupakan pembelajaran yang menghasilkan proyek dengan tugas-tugas yang menantang siswa untuk menemukan masalah, melibatkan siswa dalam pemecahan masalah, pengambilan keputusan serta memberikan kesempatan siswa untuk mengerjakan tugas dengan periode waktu tertentu sehingga dapat menghasilkan produk (N. Yahya, 2014).

Penilaian proyek dari hasil penelitian ini sangat mempengaruhi aktivitas siswa memungkinkan pembelajaran yang terpusat pada peserta didik, memberikan kesempatan siswa untuk belajar yang diintegrasikan dengan kehidupan yang nyata, seolah apa yang menjadi ide tulisan siswa yang tertuang dalam penilain proyek dengan hasil tulisan puisi secara realistis. Oleh karena itu dalam penelitian ini menghasilkan penilaian yang nyata yaitu penilaian proyek dengan implikasi bahwa siswa dapat menulis melalui konstruksi pemahaman sendiri. Sesuai dengan hasil penelitian (Nur Jannatu Na'imah, Supartono dan Sri Wardani,2015) menyatakan dengan adanya pembelajaran project based learning ini meningkatkan motivasi belajar, berinovasi, mengimplementasikan kehidupan sehari-hari, mempermudah dalam pembelajaran sehingga menumbuhkan kecakapan dalam bekerjasama secara berkelompok. 
Dari hasil pengamatan dalam proses pembelajaran project based learning ini dapat diketahui partisipasi aktif siswa baik secara individu maupun berkelompok melalui kerjasama sehingga tim kelompok tersebut dapat memecahkan permasalahan secara bersama. Meskipun hasil produk dari penilaian proyek ini secara individu tidak menutup kemungkinan peserta didik bertukar pikiran, saling empati dalam menemukan masalah sehingga terbentuk karakter kerjasama yang baik diantara peserta didik. Sesuai dengan hasil penelitian (Pradita, et al., 2015) melalui pembelajaran berbasis proyek, selain hasil belajar pada ranah kognitif, kemampuan lain siswa seperti kreativitas dan motivasi belajar dapat meningkat. Dengan tahapan penilaian proyek ini guru dapat mengetahui ketrampilan peserta didik sesuai dengan tahapan yang ditetapkan.

Hasil penelitian menunjukkan bahwa penilaian kinerja dibanding portofolio tidak ada bandingannya. Dengan kesimpulan bahwa penilain portpfolio lebih aktif dibanding dengan penilaian kinerja. Penilaian portofolio dari pembelajaran Bahasa Indonesia ini siswa mengumpulkan tugas hasil diskusi mengidentifikasi cerita rakyat, dan karya ilmiah berupa puisi. Rangkaian penilaian portofolio ini melalui tahap penilaian kinerja dan proyek. Portofolio dapat mengungkapkan ketrampilan siswa yang sebenarnya.

Arifin (2011:4) mengungkapkan bahwa penilaian portofolio ini salah satu penilaian yang mampu mengukur kompetensi peserta didik dengan cara merefleksi tugas/ karya melalui pengumpulan data yang relevan tujuan pembelajaran. Instrumen yang dimunculkan adalah tentang kerja siswa yang produktif sesuai dengan kegiatan siswa.

Beberapa latihan yang terangkum dalam rubrik penilaian portofolio ini memberikan kesempatan pada siswa untuk mengungkapkan ketrampilannya sendiri meskipun skor disesuaikan dengan indikator penilaian. Penilaian portofolio ini membuktikan bahwa siswa dapat mengungkapkan skill secara nyata dengan integrasi penggambaran kemampuan kognitif, sikap dan ketrampilan. Sesuai dengan hasil penelitian (Sri Handayani, 2013) mengemukakan bahwa dengan metode penilaian portofolio ini menunjukkan kebiasaan yang benar dalam melakukan berpikir, penguasaan yang tepat sehingga guru hanya monitoring untuk mengetahui kemajuan belajar siswa.

Berdasarkan hasil penelitian penerapan ketiga model penilaian otentik ini rata-rata skor hasil belajar yang paling rendah adalah penilaian kinerja. Dari rubrik penilaian ini mengungkapkan pengembangan pribadi, kreativitas dan keterampilan interpersonal. Dalam realita lapangan ternyata penilaian kinerja ini lebih rendah disebabkan kurang terkontronya proses kinerja siswa dalam kelas, topik yang dibahas oleh siswa belum sesuai dengan tema dari tugas.

Ketiga penilaian, yakni penilaian proyek, kinerja dan portofolio ini dapat mengaktifkan siswa dalam pembelajaran. Implementasi kurikulum 2013 ini membutuhkan peran guru untuk mengetahui strategi pembelajaran dan juga asesmen untuk siswa. Penilaian otentik dapat meningkatkan kebiasaan lebih dekat dengan Tuhannya, bersikap sosial, mempunyai kecakapan personal sesuai dengan kehidupan sehari-hari atau life skill. Dengan adanya penilaian otentik ini meningkatkan kemampuan peserta didik bersikap jujur, santun, tanggung jawab dan lain sebagainya. Guru dapat menilai peserta didik secara nyata sesuai dengan komptensinya (Kasmadi, Titik Harsiati, dan Nurhadi, 2016).

Penelitian ini memberikan rekomendasi untuk para guru khususnya mata pelajaran Bahasa Indonesia bahwa proses penilaian bukan hanya dari tes tulis (paper based testing) yang hanya mengungkapkan kemampuan kognitif saja. Penilaian otentik pembelajaran bahasa ini perlu dilakukan dalam meningkatkan kualitas penilaian siswa melalui keterlibatan siswa, proses sampai dengan tindak lanjut hasil penilaian. Pada tahap perncanaan penilaian perlu dilakukan transparansi kriteria penilaian, proses penilaian dilakukan dengan teliti setiap kinerja siswa. Penilaian otentik ini melakukan secara komphrehensif, berkelanjutan dan mampu mengungkapkan penilaian secara nyata.

\section{SIMPULAN}

Penilaian pembelajaran Bahasa Indonesia dengan penerapan tiga model penilaian yaitu penilaian proyek, kinerja dan portofolio. Rangkain penelitian ini didahului dengan pengembangan instrumen penilaian pembelajaran bahasa. Dari hasil penelitian efektivitas penerapan model penilaian otentik dari ketiga penilaian ini menunjukkan penilaian proyek paling tinggi dibanding dengan penilaian kinerja dan portofolio. Nilai rata-rata hasil belajar menunjukkan 81,06 sedangkan penilaian kinerja dan portofolio yaitu 77,69 dan 77,77. Dilanjutkan dengan uji efektifitas menunjukkan hasil P-value 0,00 dengan $\mathrm{F}$ hitung 81,628. Dengan taraf signifikansi 0,05 maka hasil penelitian menunjukkan Ho ditolak yang menyatakan ada perbedaan rata-rata skor dari ketiga penilaian otentik tersebut. Oleh karena itu 
ketiga penilaian otentik ini dapat mengukur komptensi siswa secara nyata dan terintegrasi dari penialain kognitif , afektif dan psikomotorik.

\section{UCAPAN TERIMA KASIH}

Pada kesempatan ini kami ucapkan terima kasih kepada berbagai pihak yang telah membantu dalam terlaksananya penelitian ini. Pertama, kami ucapkan terima kasih kepada Direktur DP2M Ditki yang menyeponsori penelitian serta menghibahkan dana melalui program penelitian Hibah Dikti. Kedua, ucapan terima kasih ini kami sampaikan kepada Rektor UNISNU melalui Ketua Lembaga Penelitian dan Pengabdian Masyarakat UNISNU yang telah memfasilitasi penelitian ini sehingga dapat berjalan dengan lancar. Selanjutnya, ucapan terima kasih kepada ketua KKMA02 yang telah memberikan rekomendasi kepada tim peneliti untuk terhubung dengan Ketua dan anggota MGMP KKMA02 Kabupaten Jepara. Tak lupa seluruh civitas akademika dari MA Darul Ulum Purwogondo yang telah memberi kesempatan untuk melakukan uji coba penerapan penilaian otentik ini. Terakhir kami ucapkan terima kasih kepada reviewer kami Bapak Murywantobroto, M.Pd yang telah bersedia membantu kami sebagai tim validator dan memeberikan banyak masukan agar terciptanya produk yang sesuai. Harapan kami penelitian ini memberikan manfaat keapada segala pihak yang membutuhkan dan terkait dengan peningkatan dalam pembelajaran Bahasa Indonesia.

\section{DAFTAR PUSTAKA}

Addiin, I., Redjeki, T. dan Ariani, S.R.D., 2014, Penerapan Model Pembelajaran Project Based Learning (PjBL) Pada Materi Pokok Larutan Asam Dan Basa Di Kelas XI IPA 1 SMA N 2 karanganyar tahun ajaran 2013/ 2014, Jurnal Pendidikan Kimia Program Studi Pendidikan Kimia Universitas Sebelas Maret, Vol 3, No 4, Hlm. 7-16.

Azim, S., \& Khan, M. 2012. Authentic assessment: An instructional tool to enhance students learning. Academic Research International. Vol. 2. Retrieved July 10, 2014.

Burhan \& Pujiati. 2011. "Model Penilaian Otentik dalam Pembelajaran Bahasa". Vol. 10 No.2. Hlm.116

Cordell, R. M., \& Fisher, L. F. 2010. "Reference questions as an authentic assessment of information literacy”. Franklin D. Schurz Library, Indiana University South Bend, South Bend, Indiana, USA, Emerald Group Publising Limited (www.emeraldinsight.com/00907324.htm).

Fithriya, D. 2015. "Evaluasi Otentik terhadap Penilaian Pembelajaran Sastra Tradisional pada Pembelajaran Bahasa Indonesia di Sekolah". Artikel Seminar Nasional Pendidikan Bahasa Indonesia. Surakarta : Universitas Muhammadiyah Surakarta.

Handayani, Sri. 2013. "Efektivitas Metode Pembelajaran Latihan (Drill) Dengan Sistem Penilaian Portofolio Pada Hasil Belajar Mengelola Sistem Kearsipan Kelas XI Administrasi Perkantoran SMk Negeri 1 Salatiga". Economic Education Analysis Journal. Semarang : UNNES

Hosnan, M. 2014. Pendekatan Saintifik dan Kontekstual Dalam Pembelajaran Abad 21: Kunci Sukses Implementasi Kurikulum 2013. Ghalia Indonesia.

Kasmadi, K., Harsiati, T., \& Nurhadi, N. 2016. "Pengembangan Perangkat Asesmen Otentik Keterampilan Menulis Kelas VII dalam Implementasi Kurikulum 2013”. Jurnal Pendidikan Humaniora (JPH). Vol. 4. Malang : Universitas Negeri Malang.

Kunandar, D. 2014. Penilaian Otentik. Suatu Pendekatan Praktis. Tidak ada penerbitnya

Kunandar. 2013. Penilaian Otentik (Penilaian Hasil Belajar Peserta DidikBerdasarkan Kurikulum 2013). Jakarta: Rajawali Pres

Mundilarto. 2006. Authentic Assessment Sebagai Saran Untuk Meningkatkan kemampuan Kerja Ilmiah Siswa, Physics Education Department, FMIPA: Universitas Negeri Yogyakarta

Na'imah, N. J., Supartono, S., \& Wardani, S. 2015. "Penerapan Pembelajaran Berbasis Proyek Berbantuan E-Learning untuk Meningkatkan Hasil Belajar Siswa”. Jurnal Inovasi Pendidikan Kimia. Vol. 9. Semarang : Universitas Negeri Semarang. 
Nurjananto, N., \& Kusumo, E. 2015. "Pengembangan Instrumen Penilaian Otentik Untuk Mengukur Kompetensi Peserta Didik Materi Senyawa Hidrokarbon". Jurnal Inovasi Pendidikan Kimia. Vol. 9.

Pradita, Y., Mulyani, B. dan Redjeki, T., 2015, Penerapan Model Pembelajaran Project Based Learning untuk Meningkatkan Prestasi Belajar dan Kreativitas Siswa Pada Materi Pokok Koloid Kelas XI IPA Semester Genap Madrasah Aliyah Negeri Klaten Tahun Pelajaran 2013/2014, Jurnal Pendidikan Kimia Program Studi Pendidikan Kimia Universitas Sebelas Maret, Vol 4, No 1, Hlm. 89- 96.

Rukmana, T., \& Mundilarto, M. 2016. "Keterlaksanaan Penilaian Otentik Mata Pelajaran Fisika SMA Negeri”. Jurnal Inovasi Pendidikan IPA. Vol. 2. Yogyakarta: Universitas Negeri Yogyakarta.
Taufina. 2009. Pedagogi. Jurnal Ilmiah Ilmu Pendidikan Volume IX No.1. Hlm.113, IX(1), 113-120.

Wijayanti. 2014. "Pengembangan Autentic Assessmnet Berbasis Proyek dengan Pendekatan Saintifik untuk Meningkatkan Ketrampilan Berpikir Ilmiah Mahasiswa”. Jurnal Pendidikan IPA Indonesia. Vol.3. Semarang: Universitas Negeri Semarang.

Wikanengsih. 2014. Penilaian Portofolio Berbasis Gaya Belajar Siswa Dalam Mata Pelajaran Bahasa Indonesia Sebagai Implementasi Penilaian Kurikulum 2013. Jurnal Pendidikan Bahasa dan Sastra. Vol. 14 No.1. Bandung: Fakultas Pendidikan Bahasa dan Sastra UPI

Winarti, T., \& Nurhayati, S. 2015. "Pembelajaran Praktikum Berorientasi Proyek untuk Meningkatkan Keterampilan Proses Sains dan Pemahaman Konsep". Jurnal Inovasi Pendidikan Kimia. Vol. 8 